\title{
The development of improved willow clones for eastern North America ${ }^{1}$
}

\author{
by R.F. Kopp ${ }^{2}$, L.B. Smart ${ }^{2}$, C.A. Maynard ${ }^{3}$, J.G. Isebrands ${ }^{4}$, G.A. Tuskan ${ }^{5}$ \\ and L.P. Abrahamson ${ }^{2,3}$
}

\begin{abstract}
Efforts aimed at genetic improvement of Salix are increasing in North America. Most of these are directed towards developing improved clones for biomass production, phytoremediation, nutrient filters, and stream bank stabilization in the Northeast and North-central United States. Native species are of primary interest, but a small number of clones containing non-native germplasm are also being used in the breeding program to provide valuable traits. Parent combinations for controlled crosses are being selected with the hope of maximizing the probability of producing clones exhibiting heterosis for traits of interest, such as rapid early growth, pest resistance, general adaptability, etc. The present strategy is to test as many parent clone combinations as possible, and then repeat the most promising crosses to produce large families from which the best clones will be selected for further testing. Molecular fingerprinting technology will be applied to accelerate the rate of improvement. National and international cooperation would facilitate regional clone development and promotion of willow as a bioenergy crop.
\end{abstract}

\section{Key words: Salix, biomass production, breeding, heterosis, molecular fingerprinting}

Les efforts destinés à l'amélioration génétique du Salix croissent sans cesse en Amérique du Nord. La majeure partie des efforts est concentrée sur le développement de clones améliorés pour la production de biomasse, la phytoremédiation, les filtres d'éléments nutritifs et la stabilisation des rives des cours d'eau dans le nord-est et le centre-nord des États-Unis. L'intérêt porte avant toute chose sur les espèces indigènes, mais un petit nombre de clones contenant des cellules embryonnaires non indigènes sont également utilisés dans le programme de reproduction afin d'apporter des caractéristiques intéressantes. Les combinaisons parentales pour obtenir des descendants de provenance contrôlée sont choisies dans le but de maximiser la probabilité de produire des clones démontrant une hétérogénéité des caractéristiques intéressantes, comme la croissance initiale rapide, la résistance aux ravageurs, l'adaptabilité générale, etc. La stratégie actuelle est de tester autant de combinaisons parentales de clones que possible, et de reproduire par la suite les descendants les plus prometteurs pour produire des grandes familles desquelles les meilleurs clones seront choisis pour poursuivre les tests. La technologie de l'empreinte digitale moléculaire sera utilisée pour accélérer le taux d'amélioration. La coopération nationale et internationale faciliterait le développement de clones régionaux et la promotion du saule en tant que ressource bioénergétique.

Mots-clés : Salix, production de biomasse, reproduction, hétérogénéité, empreinte digitale moléculaire

\section{History of Willow Genetic Improvement in the United States}

The documented history of Salix culture in North America starts during the period from 1840-1850 when German immigrants began producing willows for basketry in New York State and Pennsylvania. Early basket makers used native species, but soon began importing and planting willows from Europe, particularly Salix purpurea L., to increase product uniformity. The importance of selecting clones with desirable form and wood qualities that were adapted to local soils and pests was recognized in the earliest days of willow culture (Hubbard 1904). Early willow improvement efforts in the United States included field trials of 70 European clones in the 1880s (Simpson 1898). The willow basket industry in the U.S. reached a peak during the 1870s and continued until World War II.

\footnotetext{
${ }^{1}$ Presented to the 21 st Session of the International Poplar Commission, September 24-28, 2000, Vancouver, Washington, USA

${ }^{2}$ State University of New York College of Environmental Science and Forestry, Faculty of Environmental and Forest Biology, 1 Forestry Drive, Syracuse, NY 13210

${ }^{3}$ State University of New York College of Environmental Science and Forestry, Faculty of Forestry, 1 Forestry Drive, Syracuse, NY 13210

${ }^{4}$ USDA Forest Service North Central Research Station, Forestry Sciences Laboratory, 5985 Highway K, Rhinelander, WI 54501

${ }^{5}$ Oak Ridge National Laboratory, Environmental Sciences Division, P.O. Box 2008 Mail Stop 6422, Oak Ridge, TN 37831
}

Interest in growing and using poplars and willows for energy and to produce high-value chemicals and other bio-based products has increased in the United States during the past two decades, due to unstable petroleum prices, a desire to decrease dependency on imported fossil fuels, and concern about the environmental impacts of burning fossil fuel. Exceptionally high productivity rates have been achieved with hybrid poplars in the Pacific Northwest, but in the Northeast and Northcentral United States Septoria canker severely limits growth of many hybrid poplar clones (Abrahamson et al. 1990, Ostry and McNabb 1990). However, Septoria is not a disease problem for willows. Because of disease problems with hybrid poplars and reports of high biomass yields achieved with willows grown under intensive culture systems in Europe (Stott 1984, Christersson 1986), Salix became the primary genus of interest for short-rotation woody biomass production in the Northeast United States during the late 1980 s. Despite the availability of improved clones from Europe, genetic improvement of willows became necessary to obtain locally-adapted clones that express increased average production rates, improved growth form, and improved levels of pest resistance, thereby improving the economic attractiveness of growing willows for bioenergy and bio-based products.

Willows are also being planted in North America for purposes other than bioenergy with increasing frequency. Phytoremediation is an emerging technology being used for remediation of contaminated soils and filtration of water throughout North America (Isebrands 2000) and Europe 
(Perttu 1999). Phytoremediation involves the direct use of plants to decrease risks from contaminated soil, sludge, sediments, and ground water by contaminant removal, degradation, or confinement (US EPA 1998). Willows (Salix spp.), along with poplars (Populus spp.), are the most commonly used tree species for phytoremediation, due to their rapid growth rate, ease of propagation, and demonstrated contaminant uptake capability. Willows are currently under study across North America for a variety of phytoremediation and riparian buffer strip applications (Isebrands and Karnosky 2001).

Willows are widely used in riparian management in North America. Dormant willows are planted as cuttings, posts, and brush mattresses for stream bank stabilization (Schultz et al. 2000). Willows are also used to stabilize reservoir banks. Research on using willows for purification of waste-water and sludge has been in progress in Sweden since the 1980s, and Salix clones have been shown to be effective for removing large quantities of nutrients from land-applied wastes in Europe (Perttu and Kowalik 1997) and even the removal of caesium from radiocontaminated soils (Sennerby-Forsse et al. 1993). Nutrient filters composed of grasses have been successfully used for decades in North America (Young et al. 1980), but planting willows in filter strips is relatively new. Genetic improvement through selection and breeding may be necessary to develop clones specifically for planting in filter strips and clones that are more effective for stream and reservoir bank stabilization.

\section{The Salix Germplasm Resource in North America}

North America contains a Salix germplasm resource that is large, rich in genetic diversity, and virtually unexplored (Zsuffa 1988). About 70 willow species are native to North America (Fowells 1965). In addition, willow species introduced from Europe, including $S$. alba and $S$. purpurea, have become naturalized in the Northeast and North-central United States and Southeast Canada (Voss 1985). Many native, naturalized and introduced species have desirable traits for biomass production, phytoremediation, nutrient filters, and stream bank stabilization, but few of them have been tested across a wide variety of geographic areas or site types (Table 1).

A genetically diverse willow breeding population is necessary to provide sufficient variation from which clones can be developed that are adapted to a wide variety of purposes and site conditions in eastern North America. A broad genetic base in the breeding population will ensure flexibility in the breeding program and the potential to adapt to changes in types of sites desired for planting and/or pest problems. Maintaining a genetically diverse germplasm collection is critical for the long-term success of willow breeding efforts (Eriksson et al. 1984). From 1987 through 1999, researchers at the State University of New York College of Environmental Science and Forestry (SUNY-ESF) assembled a breeding population of willow containing more than 500 clones. Most of the clones came from Ontario, Canada (developed by co-operators at the University of Toronto) and from wild stands across New York and Pennsylvania, and are of species native or naturalized in the Northeast. However, because many of the clones are closely related and several species are represented by a small number of clones, the genetic diversity in this collection will be expanded in order to sustain a long-term breeding program.
The overall goal of our willow breeding population development effort is to assemble a large and diverse germplasm collection that will permit continuous improvements over many breeding generations. Specific goals include doubling the number of $S$. eriocephala clones from approximately 100 to 200 and expanding the number of $S$. purpurea clones from 20 to 150 . Based on genetic diversity estimates for $S$. eriocephala, approximately 150 clones collected from a broad geographic range should contain most of the alleles present in the species (Aravanopoulos et al. 1999). Up to 75 clones of both $S$. lucida and $S$. nigra, and a small number of clones of other Salix species will be collected. Clones from non-native species will be obtained from colleagues in Asia and Europe to provide additional useful genes that may be incorporated into production clones through advanced-generation breeding.

Efforts to expand our willow germplasm collection began in July 2000. We collected 160 willow clones from native stands across New York, Ohio, Pennsylvania, Connecticut, and Massachusetts and propagated them in a greenhouse for field-planting during spring 2001. Trees were selected based on vigour, form, and insect and disease resistance relative to other trees of the same species in the immediate vicinity. Most of the clones collected thus far were identified as $S$. eriocephala and $S$. purpurea with smaller numbers of $S$. lucida and $S$. nigra also included. Collections will be completed in Michigan, Minnesota and Wisconsin during 2001.

All of the new clones collected for this project will be planted in observation trials on two sites, one in New York and the other in Wisconsin. The purposes of these trials are: 1) to assess the phenotypic variability in new clones collected from a wide geographic region, 2) to determine how the clones perform in locations distant from their origin, and 3) to identify clones for future breeding work with desirable traits. The trials will also serve as clonal archives duplicated on two sites to minimize the chance of losing clones. Intra- and inter-specific hybrid clones produced in our previous breeding efforts will be included in these trials to compare with clones collected from native stands. Production clones currently being planted will also be included in these trials to serve as controls ("commercial checks").

Clones will be selected for use in the first parental generation based on measurements and observations completed during the first and second growing seasons after the initial coppice. Selection criteria will vary, depending on the desired end-use of the clones. Statistical analyses will be used to determine if clonal differences exist in initial height growth, average stem diameter, stool dry weight, number of stems per stool, disease and/or insect resistance, and crown form (Table 2) and if clone-by-site interaction is large. If large cloneby-site interactions are observed, then selection of superior clones will be accomplished in a site-specific manner. Large variability will be maintained in the base breeding population to allow selection for numerous end-uses.

\section{Background on Genetic Improvement of Willow in North America}

A limited amount of willow breeding and selection has been conducted in North America. Native species were bred in the 1980 s by researchers at the University of Toronto to produce $\mathrm{F}_{1}$ intra- and interspecific hybrids for bioenergy production (Mosseler 1985). Controlled breeding of S. eriocephala and 


\begin{tabular}{|c|c|c|c|}
\hline $\begin{array}{l}\text { Sectional } \\
\text { Classification }^{1}\end{array}$ & Species & Form & Native Range \\
\hline \multicolumn{4}{|l|}{ Subgenus Salix } \\
\hline Humboltianae & $\begin{array}{l}\text { S. amygdaloides Anderss. } \\
\text { S. nigra Marsh }\end{array}$ & $\begin{array}{l}\text { tree } \\
\text { tree }\end{array}$ & $\begin{array}{l}\text { N.C. USA } \\
\text { Eastern USA }\end{array}$ \\
\hline Salix & $\begin{array}{l}\text { S. alba } \mathrm{L} \text {. } \\
\text { S. fragilis } \mathrm{L} \text {. }\end{array}$ & $\begin{array}{l}\text { tree } \\
\text { tree }\end{array}$ & $\begin{array}{l}\text { Central Europe } \\
\text { Central Europe }\end{array}$ \\
\hline Subalbae & S. matsudana Koidz. & tree & Northern China \\
\hline Salicaster & S. lucida Muhl. & shrub & Eastern N. America \\
\hline Longifoliae & S. exigua Nutt. & shrub & North America \\
\hline \multicolumn{4}{|l|}{ Subgenus Vetrix } \\
\hline Vetrix & $\begin{array}{l}\text { S. bebbiana Sarg. } \\
\text { S. discolor Muhl. } \\
\text { S. petiolaris Smith }\end{array}$ & $\begin{array}{l}\text { shrub } \\
\text { shrub } \\
\text { shrub }\end{array}$ & $\begin{array}{l}\text { transcontinental } \\
\text { North America } \\
\text { North America }\end{array}$ \\
\hline Vimen & $\begin{array}{l}\text { S. dasyclados Wimm. } \\
\text { S. pellita Anderss. } \\
\text { S. sachalinensis Schmidt. } \\
\text { S. viminalis L. }\end{array}$ & $\begin{array}{l}\text { tree } \\
\text { shrub } \\
\text { shrub } \\
\text { shrub }\end{array}$ & $\begin{array}{l}\text { C. Europe to E. Siberia } \\
\text { E. Canada } \\
\text { Japan } \\
\text { C. Europe to E. Siberia }\end{array}$ \\
\hline Cordatae & S. eriocephala Muhl. & shrub & North America \\
\hline Helix & $\begin{array}{l}\text { S. miyabeana Seeman } \\
\text { S. purpurea L. }\end{array}$ & $\begin{array}{l}\text { shrub } \\
\text { shrub }\end{array}$ & $\begin{array}{l}\text { E. Siberia, China } \\
\text { Europe }\end{array}$ \\
\hline
\end{tabular}

${ }^{1}$ Sectional classification according to Dorn (1976).

S. sericea by researchers at Vassar College in Poughkeepsie, NY yielded intra- and interspecific hybrids, which were used in studies on herbivore preference and gene introgression (Roche and Fritz 1997, Hardig et al. 2000). Our group initiated a program of controlled willow breeding in 1998 to produce willows for bioenergy or conversion to high-value chemicals. Native and introduced species were used to produce $F_{1}$ intra- and interspecific progeny in 1998 , and some of these clones were crossed in 2000 to produce $\mathrm{F}_{2}$ progeny (Kopp et al. 2000). Thus, very few multiple-generation, structured Salix pedigrees exist today that could be useful in gene expression studies.

Interspecific hybridization of willows may yield superior clones through the combination of desirable traits, heterosis, and greater phenotypic stability in varied environments (Stettler et al. 1996). Many examples of successful interspecific hybridization with willows have been reported (Argus 1974, Hathaway 1977, Zsuffa et al. 1984, Larsson 1998). However, interspecific hybridization of willow species native to North America generally resulted in $\mathrm{F}_{1}$ hybrid progeny, which often had decreased vigour and poor survival, though some individuals exceeded the growth of either parent (Mosseler 1990). S. eriocephala females failed to yield viable seed in any interspecific hybridization attempts in studies completed by Mosseler (1990) or Kopp (2000). S. eriocephala is known to be difficult to hybridize when it is the pistillate parent because of inhibition of pollen tube growth (Mosseler 1989). These findings suggest that S. eriocephala males should be used in interspecific hybridization efforts with this species.

Vigorous growth by $S$. viminalis in northern Europe is well documented (Gullberg 1993, Rönnberg-Wästljung and Gullberg 1996, Larsson 1998), but various insect pests, par- ticularly potato leafhoppers (Empoasca fabae Harris), cause substantial damage and associated poor growth of this species in the Northeast and North-central United States (Kopp 2000). Preliminary information from an unreplicated field trial suggests that progeny of crosses between $S$. viminalis and $S$. miyabeana, an Asian species, may be less susceptible to potato leafhopper attack. If substantiated, $S$. viminalis germplasm may contribute to the production of high-yielding hybrid clones for use in North America once genes for resistance to potato leafhopper can be introduced.

\section{Role of Biotechnology in Willow Tree Improvement}

Application of biotechnology to willow tree improvement may accelerate the rate of genetic gain. Recently developed molecular techniques may enable willow breeders to narrow the pool of candidate breeding trees, so that effort is not wasted on crosses that have low probability of producing desirable progeny. Molecular markers can help to characterize populations, estimate genetic variability within and among wild or generated populations, and identify individuals at a young age that will express a trait at maturity (Dinus and Tuskan 1997). Molecular fingerprinting can be used to produce genetic maps for traits of interest. A genetic map including restriction fragment length polymorphism (RFLP), sequence-tagged sites (STSs), and RAPD markers was produced for a hybrid poplar family derived from an inbred $\mathrm{F}_{2}$ family (Bradshaw et al. 1994). This map was used to identify quantitative trait loci (QTLs) with large effects on growth, form, and phenology (Bradshaw and Stettler 1995). Similar techniques may be applied to willow breeding. We have generated populations of $\mathrm{F}_{1}$ and $\mathrm{F}_{2}$ proge- 
Table 2. Traits of interest for willow biomass production.

\begin{tabular}{ll}
\hline Mensurational Traits & Physiological Traits \\
\hline Biomass production $^{\mathrm{a}}$ & Sylleptic shoot production \\
Stem height $^{\mathrm{a}}$ & Insect susceptibility $^{\mathrm{a}}$ \\
Stem diameter $^{\mathrm{a}}$ & Pathogen susceptibility $^{\mathrm{a}}$ \\
Number of stems $^{\mathrm{a}}$ & Mammal browse susceptibility $^{\mathrm{a}}$ \\
Stool form $^{\mathrm{a}}$ & Herbicide tolerance \\
Survival $^{\mathrm{a}}$ & Foliage chemistry $^{\mathrm{b}}$ \\
Wood density $^{\mathrm{b}}$ & Cuticle thickness/chemistry $^{\mathrm{b}}$ \\
& Leaf area \\
& Leaf nitrogen percentage \\
& Leaf weight/unit area \\
& Photosynthesis rate \\
& Budburst date \\
& Growth cessation date \\
\end{tabular}

${ }^{a}$ Traits that will be measured on trees at all sites.

${ }^{\mathrm{b}}$ Traits that will be measured as time and funding permit.

ny, which may be amenable to molecular mapping, and are currently developing AFLP and microsatellite markers for willow.

Genetic transformation research with Salix is not as advanced as for Populus. In Sweden, transformation of a limited number of Salix clones was successful using Agrobacterium tumefaciens, but plantlets could not be produced from transformed calli (Vahala et al. 1989). Salix lucida_was transformed using A. tumefaciens and plantlets were produced, but the transferred genes were not stable (Xing 1995). Efforts to develop a transformation system for Salix are in progress at SUNY-ESF. Genes controlling flowering in Salix will be identified, with the objective of altering their expression in transgenic plants to produce clones that do not flower. As noted above, this strategy might then be used to essentially eliminate the possibility of introgression of genes from introduced species into natural populations of willow through cross-pollination.

\section{Willow Breeding Strategy for the Northeast and North-central United States and South- east Canada}

We have devised a strategy for the genetic improvement of willows with the goal of rapidly producing clones that are adapted to growth in intensively cultured biomass plantings in the Northeast and North-central United States and Southeast Canada (Fig. 1). The system can be used to produce clones for other purposes by altering the selection criteria. This strategy is based on our initial results and from reports on improvement efforts in Sweden and Canada. Briefly, the strategy assumes that hybrid vigour for growth rate or other traits of interest can be obtained by controlled intra- and inter-specific mating and depends on identifying specific favourable combinations of parents. Because reliable prediction of desirable parent clone combinations is not currently possible, large numbers of crosses will be completed yielding many families with small numbers of progeny, which will be field tested (Fig. 1). Crosses that appear promising will be repeated to produce large numbers of progeny. High selection intensity will be applied to these large families and selected individuals will be vegetatively propagated, resulting in large genetic gain.

Efforts are in progress to identify crosses that have potential to generate exceptional progeny and are worth repeating to generate large families. More than 120 relatively small fullsib families were produced by controlled pollination from 1998 to 2000 (Kopp 2000). Progeny from these crosses are currently being tested in field trials. More crosses to identify favourable family combinations (approximately 50) will be completed when flowers and juvenile growth and pest resistance data are available from clones collected or produced from 1998 to 2001. Parent clone combinations will be selected to maximize the probability of generating progeny exhibiting heterosis for biomass production or other traits of interest. Molecular fingerprint data may also be used to identify particular parent combinations that are likely to yield desirable clones based on maximizing the amount of molecular diversity among crossed genotypes.

After large numbers of families containing small numbers of progeny have been evaluated in the field, five to 10 crosses will be selected that are likely to yield progeny exhibiting outstanding performance. These selected crosses will be repeated to produce families with large numbers of progeny. Data from small families produced from 1998 to 2000 will be available in 2001, so that the first set of crosses to produce large families will be made during 2002. A second set of selected crosses to produce large families will be completed when new, promising parent combinations are identified.

Selection of exceptional individuals to be propagated for operational plantings should ideally be from families exhibiting large variability with 500 or more individuals (Tuskan 1997). Such families will be evaluated in the field in a non-replicated screening trial. The top $5 \%$ of the progeny in each family will be selected based on measurements of traits of interest completed at the end of the first coppice-growing season. Large numbers of clonal replicates from each selected clone will be produced using small one- or two-bud cuttings, then transplanted to a fertilized, irrigated cutting orchard. Dormant one-year-old stems from the cutting orchard will be harvested to provide unrooted cuttings for clone-site trials that will be established using operational spacing and cultural practices on at least two sites.

Basic genetic studies are necessary to obtain heritability estimates for traits of interest. Progeny tests containing 34 fullsib $S$. eriocephala families from an $8 \times 7$ factorial mating design completed during 1998 were established in 2000 to provide these estimates (Kopp 2000). Ten randomly selected seedlings from each family and the parents were vegetatively propagated and dormant, hardwood cuttings were planted in replicated tests at LaFayette and Tully, NY. These tests will permit estimates of general combining ability, specific combining ability, additive and non-additive genetic variance components and genotype-by-environment interaction for any traits of interest.

Advanced-generation breeding strategies, i.e., $\mathrm{F}_{3}$ and beyond, are not clearly defined at this point in willow development. There are multiple, equally likely alternatives that may ultimately prove useful. It is unlikely that insights into which alternative should be pursued will come from breeding programs in any other woody species. Even with Populus, the generation intervals are considerably longer than with Salix. As a result, a willow breeding program will face decisions on advanced-generation breeding well before most tree breeding programs are into their $\mathrm{F}_{2}$ generation. Therefore, concessions need to be made early in the formation of any willow improvement program that will 1) allow flexibility in pursu- 


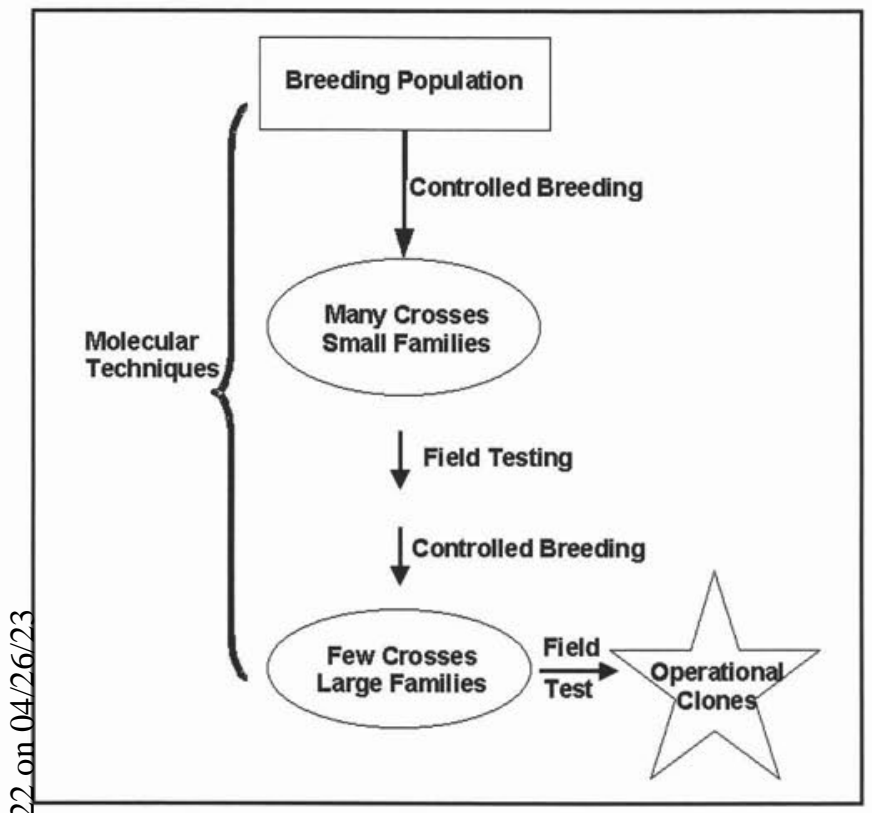

Fig. 1. Generalized willow breeding strategy for the Northeast and NNNorth-central United States.

ing alternative strategies and 2) quickly determine the approOpriate advanced-generation approach.

$\dot{t}$ Today, there is considerable debate on whether willow Ifiganced-generations should be formed using simple recurront selection, reciprocal recurrent selection or to abandon these istrategies altogether for random wide crossing among unre-

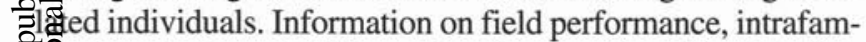
if phenotypic variability, and molecular diversity will allow Sur to choose from among one of these three alternatives. For Tesample, if heterosis is mainly the result of overdominance and Tintrafamily phenotypic variances are high, then reciprocal recurrent selection may be the most appropriate advanced-generzation strategy.

Based on conservative estimates, it is expected that the strat20 gy described above will initially result in 10 to $20 \%$ gains in biomass production each generation. Willow breeding in SSweden completed since 1987 yielded clones with 10 to $20 \%$ $\bar{U}_{\text {increases in biomass production compared with commercial }}$ Echeck clones (Larsson 1998). Because most of the clones cur[rently being used in operational biomass plantings in New York Iwere selected from wild populations or from $\mathrm{F}_{1}$ populations that had been tested in small plots on a minimal number of sites, improvements exceeding $10 \%$ to $20 \%$ are anticipated. Hybrids between Populus trichocarpa and P. deltoides showed more than twice the growth rate of either parent (Stettler et al. 1988). Identifying willow species combinations resulting in similar levels of heterosis may be possible.

The strategy described above includes importing nonnative willow species to North America as well as making use of naturalized species. Importing non-native willows is desired, because some species or clones have unique traits and presumably unique alleles that are not present in the native species. All imports are completed under strict compliance with USDA guidelines as pollen, seeds, or dormant unrooted cuttings, so the risk of pest introduction is minimized. Many steps are taken to reduce the risk of introduced willows becoming pests or of introgression of their genes into the native gene pool. Non-native clones or their progeny will be used in biomass plantings and not in riparian areas, so there is little chance that they could spread by natural vegetative propagation. Pollen-pistil incongruity and asynchronous flowering prevents successful natural interspecific hybridization among many willow species (Mosseler 1989). The potential for hybridization of introduced species with natives will also be evaluated prior to clone release. Trees produced by interspecific hybridization frequently do not flower (Mosseler 1990), so efforts are in progress to identify species combinations that can be bred and yield infertile progeny with desired growth characteristics. In addition, production clones may be rendered sterile through the use of genetic transformation in an effort to eliminate gene flow into native stands (Strauss et al. 2000).

\section{Conclusions}

Willow genetic improvement in North America is at an early stage of development. Breeding with willows native to North America plus several naturalized and non-native species has been completed, providing a starting point for future breeding activities. The breeding strategy described above may be modified as new information becomes available. Critical assumptions of the proposed strategy are that heterosis can be obtained by mating appropriate pairs of clones and controlled matings will result in families with large variability. Success of the breeding program depends on assembling a collection of genetically diverse germplasm. Collection efforts are focused on native species gathered from a broad geographic range, but a limited number of non-native clones are desired to maximize genetic diversity and breeding options. Cooperation with willow breeders around the world is desired, so that germplasm can be exchanged, although environmental stewardship will be a priority when considering large-scale deployment of non-native material.

\section{Acknowledgements}

The authors wish to thank the agencies that are financially supporting this research including the New York State Energy Research and Development Authority, the Oak Ridge National Laboratory, managed by UT-Battelle, LLC, for the U.S. Department of Energy under contract DE-AC0500OR22725 and the United States Department of Agriculture.

\section{References}

Abrahamson, L.P., E.H. White, C.A. Nowak, R.D. Briggs and D.J. Robison. 1990. Evaluating hybrid poplar clonal growth potential in a three-year-old genetic selection field trial. Biomass 21: 101-114. Aravanopoulos, F.A., K.H. Kim and L. Zsuffa. 1999. Genetic diversity of superior Salix clones selected for intensive forestry plantations. Biomass and Bioenergy 16: 249-255.

Argus, G.W. 1974. An experimental study of hybridization and pollination in Salix (willow). Canadian Journal of Botany 52: 1613-1619. Bradshaw, H.D. and R.F. Stettler. 1995. Molecular genetics of growth and development in Populus. IV. Mapping QTLs with large effects on growth, form, and phenology traits in a forest tree. Genetics 139: 963-973.

Bradshaw, H.D., M. Villar, B.D. Watson, K.G. Otto, S. Stewart and R.F. Stettler. 1994. Molecular genetics of growth and development in Populus. III. A genetic linkage map of a hybrid poplar composed of RFLP, STS, and RAPD markers. Theoretical and Applied Genetics 89: 167-178. 
Christersson, L. 1986. High technology biomass production by Salix clones on a sandy soil in southern Sweden. Tree Physiology 2: 261-272.

Dinus, R.J. and G.A. Tuskan. 1997. Integration of molecular and classical genetics: a synergistic approach to tree improvement. USDA Forest Service General Technical Report RM-GTR-297. Chapter 29: 220-235.

Dorn, R.D. 1976. A synopsis of American Salix. Canadian Journal of Botany 54: 2769-2789.

Eriksson, G., U. Gullberg and H. Kang. 1984. Breeding strategy for short rotation woody species. In K. Perttu (ed.). Ecology and Management of Forest Biomass Production Systems, Report 15. pp. 199-216. Swedish University of Agricultural Sciences, Uppsala, Sweden.

Fowells, H.A. 1965. Silvics of Trees of the United States. Agricultural Handbook 271. USDA Forest Service, Washington, DC. 762 p. Gullberg, U. 1993. Towards making willows pilot species for coppicing production. The Forestry Chronicle 69: 721-726.

Hardig, T.M., S.J. Brunsfeld, R.S. Fritz, M. Morgan and C.M. Orians. 2000. Morphological and molecular evidence for hybridization and introgression in a willow (Salix) hybrid zone. Molecular Ecology 9: 9-24.

Hathaway, R.L. 1977. Early growth of Salix matsudana $\mathrm{x}$ alba hybrids. New Zealand Journal of Forestry Science 7: 207-213.

Hubbard, W.F. 1904. The basket willow. USDA Bureau of Forestry Bulletin No. 46. 100 p.

Isebrands, J.G. 2000. Activities related to poplar and willow cultivation and utilization. Report of the National Poplar Commission of the USA. Period: 1996-2000. $21^{\text {st }}$ Session of the International Poplar Commission, Portland, Oregon, September 24-30, 2000. 13 p.

Isebrands, J.G. and D.F. Karnosky. 2001. Environmental benefits of poplar culture. In D.I. Dickmann et al. (eds.). Poplar Culture in North America. NRC Research Press, Ottawa, Ontario, Canada (in press).

Kopp, R.F. 2000. Genetic Improvement of Salix Using Traditional Breeding and AFLP Fingerprinting. Ph.D. Dissertation. State University of New York College of Environmental Science and Forestry, Syracuse, NY. 175 p.

Kopp, R.F., L.B. Smart, L.P. Abrahamson, C.A. Maynard and J.G. Isebrands. 2000. Genetic improvement of Salix for the Northeast and North-Central United States. In J.G. Isebrands and J. Richardson (compilers). USDA Forest Service North Central Research Station General Technical Report NC-215.21 ${ }^{\text {st }}$ Session of the International Poplar Commission (IPC 2000) Poplar and Willow Culture: Meeting the Needs of Society and the Environment.

Larsson, S. 1998. Genetic improvement of willow for short-rotation coppice. Biomass and Bioenergy 15: 23-26.

Mosseler, A. 1985. An overview of Salix breeding in Ontario. Proceedings of the $20^{\text {th }}$ Meeting of the Canadian Tree Improvement Association. August 19-22, 1995, Quebec City, QC. pp. 142-150.

Mosseler, A. 1989. Interspecific pollen-pistil incongruity in Salix. Canadian Journal of Forest Research 19: 1161-1168.

Mosseler, A. 1990. Hybrid performance and species crossability relationships in willows (Salix). Canadian Journal of Botany 68: 2329-2338.

Ostry, M.E. and H.S. McNabb. 1990. Minimizing disease injury to hybrid poplars. Journal of Environmental Horticulture 8: 96-98. Perttu, K.L. 1999. Environmental and hygienic aspects of willow coppice in Sweden. Biomass and Bioenergy 16: 291-297.

Perttu, K. and P.J. Kowalik. 1997. Salix vegetation filters for purification of waters and soils. Biomass and Bioenergy 12: 9-19. Roche, B.M. and R.S. Fritz. 1997. Genetics of resistance of Salix sericea to a diverse community of herbivores. Evolution 51: $1490-1498$.
Rönnberg-Wästljung, A.C. and U. Gullberg. 1996. Genetic relationships between growth characters in Salix viminalis grown in Sweden. Theoretical and Applied Genetics 93: 15-21.

Schultz, R.C., J.P. Colletti, T.M. Isenhart, C.O. Marquez, W.W. Simpkins and C.J. Ball. 2000. Riparian forest buffer practices. In W.J. Rietveld, R.F. Fisher and H.E. Garrett (eds.). North American Agroforestry: An Integrated Science and Practice. pp. 189-282. American Society of Agronomy, Madison, WI.

Sennerby-Forsse, L., D. Melin and K. Rosen. 1993. Uptake and distribution of radiocesium in fast-growing Salix viminalis. Journal of Sustainable Forestry 1: 93-103.

Simpson, J.M. 1898. Osier culture. United States Department of Agriculture Bulletin No. 19. 27 p.

Stettler, R.F., R.C. Fenn, P.E. Heilman and B.J. Stanton. 1988 Populus trichocarpa $\mathrm{x}$ Populus deltoides hybrids for short rotation culture: variation patterns and 4-year field performance. Canadian Journal of Forest Research 18: 745-753.

Stettler, R.F., L. Zsuffa and R. Wu. 1996. The role of hybridization in the genetic manipulation of Populus. In R.F. Stettler, H.D. Bradshaw Jr., P.E. Heilman and T.M. Hinckley (eds.). Biology of Populus and Its Implications for Management and Conservation. Part I, Chapter 4. pp. 87-112. NRC Research Press, National Research Council of Canada, Ottawa, ON.

Stott, K.G. 1984. Improving the biomass potential of willow by selection and breeding. In K. Perttu (ed.). Ecology and Management of Forest Biomass Production Systems. Report 15. pp. 233-260. Swedish University of Agricultural Science, Uppsala, Sweden.

Strauss, S.H., K. Raffa and P. List. 2000. Ethics and transgenic plantations. Journal of Forestry 98: 47-48.

Tuskan, G.A. 1997. Clonal forestry, heterosis and advancedgeneration breeding. Proceedings of the 24th Biennial Southern Forest Tree Improvement Conference, Orlando, FL, June 9-12, 1997. pp. 390-392.

U.S. Environmental Protection Agency (EPA). 1998. A citizen's guide to phytoremediation. EPA 542-F-98-011. Technology Fact Sheet. Office of Solid Waste and Emergency Response (5102G). 6 p.

Vahala, T., P. Stabel and T. Eriksson. 1989. Genetic transformation of willows (Salix spp.) by Agrobacterium tumefaciens. Plant Cell Reports 8: 55-58.

Voss, E.G. 1985. Michigan Flora: A guide to the identification and occurrence of the native and naturalized seed-plants of the State. Part II. Dicots (Saururaceae-Cornaceae). Cranbrook Institute of Science, Ann Arbor, MI. 724 p.

Xing, Z. 1995. Genetic transformation and regeneration of willows (Salix spp). Ph.D. Dissertation, SUNY College of Environmental Science and Forestry, Syracuse, NY. 130 p.

Young, R.A., T. Huntrods and W. Anderson. 1980. Effectiveness of vegetated buffer strips in controlling pollution from feedlot runoff. Journal of Environmental Quality 9: 483-487.

Zsuffa, L. 1988. A review of progress in selecting and breeding North American Salix species for energy plantations at the Faculty of Forestry, University of Toronto, Canada. International Energy Agency Proceedings from Willow Breeding Symposium August 31-September 1, 1987. Research Notes 41: pp. 41-51. Swedish University of Agricultural Sciences, Uppsala, Sweden.

Zsuffa, L., A. Mosseler and Y. Raj. 1984. Prospects for interspecific hybridization in willow for biomass production. In K. Perttu (ed.). Ecology and Management of Forest Biomass Production Systems. Report 15. pp. 261-281. Swedish University of Agricultural Sciences, Uppsala, Sweden. 